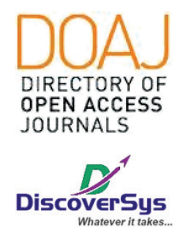

Published by DiscoverSys

\section{Uji efektivitas ekstrak kunyit (Curcuma longa) terhadap daya hambat pertumbuhan bakteri Streptococcus mutans}

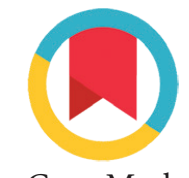

CrossMark

\author{
I Nyoman Candra Kumara, ${ }^{1 *}$ I Gusti Agung Sri Pradnyani, ${ }^{2}$ \\ I Gusti Ayu Fienna Novianthi Sidiarta
}

\title{
ABSTRACT
}

Background: Dental caries is a multifactorial disease characterized by dental tissue damage caused by the production of bacterial acids. The bacteria play the most role in the occurrence of caries is Streptococcus mutans. Turmeric extract (Curcuma longa) has been studied can inhibit bacterial growth because it contains essential oils and curcumin. The purpose of this study was to determine the inhibitory power of turmeric extract $5 \%, 10 \%, 20 \%$, and $40 \%$ on the growth of Streptococcus mutans bacteria.

Methods: Studies with true experimental design using a post test only control group design have been carried out on Streptococcus mutans bacteria. Turmeric extract was made by maceration method into $96 \%$ ethanol so that the required concentration was obtained $(5 \%, 10 \%$,
$20 \%$, dan $40 \%$ ). The inhibition testing is done by the disk-diffusion method. Data were analyzed using the Kruskal-Wallis test on SPSS version 20 due to the data were not normally distributed.

Results: The results showed that phytochemical assessment of turmeric extract showed positive results on phenol, essential oil, saponins, tannins, and flavonoids. The average value of the inhibitory zone diameter of Streptococcus mutans bacteria formed in turmeric extract concentrations of $5 \%, 10 \%, 20 \%$, and $40 \%$ is $0 \mathrm{~mm}$ where there are significant differences compared to positive controls $(P<0.05)$

Conclusion: Various doses of turmeric extract couldn't inhibit the growth of Streptococcus mutans bacteria

Keyword: turmeric extract, inhibitory power, Streptococcus mutans

Cite This Article: Kumara, I.N.C., Pradnyani, I.G.A.S., Sidiarta, I.G.A.F.N. 2019. Uji efektivitas ekstrak kunyit (Curcuma longa) terhadap daya hambat pertumbuhan bakteri Streptococcus mutans. Intisari Sains Medis 10(3): 462-467. D0I: 10.15562/ism.v10i3.350

\section{ABSTRAK}

Latar Belakang: Karies gigi merupakan penyakit multifaktorial yang ditandai dengan kerusakan jaringan keras gigi yang disebabkan oleh produksi asam bakteri. Bakteri yang paling berperan dalam terjadinya karies adalah Streptococcus mutans. Ekstrak kunyit (Curcuma longa) telah diteliti mampu menghambat pertumbuhan bakteri karena mengandung minyak atsiri dan kurkumin. Tujuan dari penelitian ini adalah untuk mengetahui daya hambat ekstrak kunyit konsentrasi 5\%, 10\%, 20\%, dan 40\% terhadap pertumbuhan bakteri Streptococcus

'Program Studi Sarjana Kedokteran Gigi, Fakultas Kedokteran, Universitas Udayana, Bali, Indonesia

2Profesi Dokter Gigi, Fakultas Kedokteran, Universitas Udayana, Bali, Indonesia

\section{*Korespondensi:}

I Nyoman Candra Kumara; Program Studi Sarjana Kedokteran Gigi, Fakultas Kedokteran, Universitas Udayana, Bali, Indonesia; candra.kumara45@gmail.com

Diterima: 11-11-2018

Disetujui: 17-12-2018

Diterbitkan: 01-12-2019

\section{mutans.}

Metode: Studi dengan desain true experimental menggunakan rancangan post test only control group design telah dilakukan pada bakteri Streptococcus mutans. Ekstrak kunyit dibuat dengan metode maserasi ke dalam pelarut etanol $96 \%$ sehingga diperoleh
Kata kunci: ekstrak kunyit, daya hambat, Streptococcus mutans

\section{PENDAHULUAN}

Karies gigi merupakan penyakit gigi dan mulut yang paling umum terjadi di dunia. Kasus karies gigi pada gigi permanen diperkirakan terjadi pada konsentrasi yang diperlukan (5\%, 10\%, 20\%, dan 40\%). Pengujian daya hambat dilakukan dengan metode disk-diffusion. Data dianalisis menggunakan uji Kruskal-Wallis pada SPSS versi 20 dikarenakan data tidak berdistribusi normal.

Hasil: Hasil penelitian menunjukkan bahwa pemeriksaan fitokimia ekstrak kunyit menunjukan hasil positif terhadap fenol, minyak atsiri, saponin, tanin, dan flavonoid. Nilai rata-rata diameter zona hambat terhadap bakteri Streptococcus mutans yang terbentuk pada ekstrak kunyit konsentrasi 5\%,10\%, 20\%, dan 40\% adalah sebesar $0 \mathrm{~mm}$ dimana terdapat perbedaan yang bermakna dibandingkan dengan kontrol positif $(p<0,05)$.

Kesimpulan: Berbagai dosis ekstrak kunyit menunjukkan tidak dapat menghambat pertumbuhan bakteri Streptococcus mutans.

Cite Pasal Ini: Kumara, I.N.C., Pradnyani, I.G.A.S., Sidiarta, I.G.A.F.N. 2019. Uji efektivitas ekstrak kunyit (Curcuma longa) terhadap daya hambat pertumbuhan bakteri Streptococcus mutans. Intisari Sains Medis 10(3): 462-467. D0I: 10.15562/ism.v10i3.350

$36 \%$ populasi di dunia. ${ }^{1}$ Prevalensi karies aktif di Indonesia pada tahun 2007, yaitu 43,4\%, sedangkan prevalensi karies aktif pada tahun 2013, yaitu 
$53,2 \%{ }^{2,3}$ Hal ini menunjukkan adanya peningkatan kejadian karies gigi di Indonesia.

Karies gigi merupakan penyakit multifaktorial yang ditandai dengan kerusakan jaringan keras gigi yang disebabkan karena produksi asam oleh hasil fermentasi bakteri dari sisa-sisa makanan yang ada di permukaan gigi. ${ }^{1,4}$ Salah satu faktor penyebab karies adalah bakteri. Bakteri yang paling berperan dalam terjadinya karies adalah bakteri Streptococcus mutans. ${ }^{5,6}$ Streptococcus mutans merupakan bakteri Gram positif berbentuk kokus dan merupakan flora normal pada rongga mulut. ${ }^{7,8}$ Streptococcus mutans memiliki kemampuan untuk memfermentasikan karbohidrat menjadi asam (asidogenik) dan mampu hidup di lingkungan yang asam (asidurik).5,9 Kemampuan menghasilkan asam ini mengakibatkan $\mathrm{pH}$ rongga mulut menurun sehingga mempercepat proses demineralisasi, yaitu larutnya kristal hidroksiapatit penyusun email dan dentin sehingga dapat terbentuk kavitas. ${ }^{7,9}$

Berbagai metode digunakan untuk mencegah terjadinya karies, salah satunya dengan menghambat pertumbuhan bakteri penyebab karies dengan menggunakan obat herbal. Obat herbal digunakan karena kandungan zat herbalnya dianggap tidak menimbulkan efek samping dan aman. Zat herbal didapatkan dari ekstraksi bagian-bagian tumbuhan yang masih segar atau sudah dikeringkan. ${ }^{10}$

Penelitian menggunakan zat herbal telah dilakukan oleh beberapa peneliti. Pangemanan dkk. pada tahun 2016 meneliti ekstrak kunyit (Curcuma longa) konsentrasi 5\%, 10\%, 20\%, dan 40\% untuk menghambat pertumbuhan bakteri Staphylococcus aureus dan Pseudomonas sp. Hasil dari penelitian tersebut menunjukkan bahwa ekstrak kunyit konsentrasi 5\%, 10\%,20\%, dan 40\% dapat menghambat pertumbuhan bakteri Staphylococcus aureus dan Pseudomonas sp. ${ }^{11}$

Efektivitas daya hambat ekstrak kunyit terhadap pertumbuhan bakteri Streptococcus mutans belum pernah diteliti sebelumnya. Berdasarkan latar belakang di atas, penulis tertarik untuk meneliti efektivitas daya hambat ekstrak kunyit konsentrasi $5 \%, 10 \%, 20 \%$, dan $40 \%$ terhadap pertumbuhan bakteri Streptococcus mutans.

\section{METODE PENELITIAN}

\section{Desain dan Sampel Penelitian}

Jenis penelitian yang dilakukan pada penelitian ini adalah penelitian true experimental dengan rancangan penelitian yang digunakan adalah post test only control group design. Sampel pada penelitian ini menggunakan sampel bakteri sehingga jumlah sampel ditentukan dengan memakai rumus standar pengulangan baku pengujian bakteri, yaitu rumus
Federer ${ }^{12}$ dimana tiap kelompok perlakuan dilakukan pengulangan minimal 4 kali.

\section{Tempat dan waktu penelitian}

Pembuatan ekstrak kunyit dilakukan di Laboratorium Sumberdaya Genetika dan Biologi Molekuler Pascasarjana Universitas Udayana, Denpasar. Uji fitokimia dilakukan di Laboratorium Kimia Fakultas Matematika dan Ilmu Pengetahuan Alam Universitas Udayana, Bukit Jimbaran. Uji daya hambat ekstrak kunyit terhadap pertumbuhan bakteri Streptococcus mutans dilakukan di Laboratorium Mikrobiologi Fakultas Kedokteran Universitas Udayana, Denpasar. Penelitian dilakukan selama 3 bulan, yaitu dari bulan Desember 2017 - Februari 2018.

\section{Pembuatan ekstrak kunyit}

Rimpang kunyit yang berasal dari Pupuan, Tabanan dikumpulkan 1,5 kg. Rimpang dikupas dan dibersihkan di bawah air mengalir. Rimpang yang sudah bersih diiris menggunakan pisau di atas papan potong dan diletakkan di nampan untuk dikeringkan di bawah sinar matahari agar kering.

Setelah kering, rimpang kemudian diblender hingga halus. Simplisia serbuk rimpang kunyit yang didapat dari hasil blender kemudian dimaserasi. Maserasi dilakukan dengan merendam simplisia rimpang kunyit ke dalam 2 liter etanol 96\% selama 3 hari dan didiamkan di dalam wadah kedap. Simplisia yang didiamkan di dalam wadah kedap diaduk dengan besi pengaduk di antara waktu perendaman. Hasil maserasi kemudian disaring dengan kertas saring. Hasil dari proses tersebut didapatkan ekstrak cair pertama. Residu dari ekstrak cair pertama dimaserasi kembali dengan merendamnya ke dalam 1 liter etanol 96\% selama 1 hari dan diaduk. Residu yang sudah direndam selama 1 hari kemudian disaring. Hasil dari proses tersebut didapatkan ekstrak cair kedua yang selanjutnya digabung dengan ekstrak cair pertama.

\section{Pengujian fitokimia}

Uji fitokimia dilakukan untuk mengetahui kandungan zat flavonoid, saponin, steroid, alkaloid, fenol, glikosida, tanin, dan minyak atsiri. Pada uji flavonoid sebanyak $40 \mathrm{mg}$ ekstrak dilarutkan ke dalam etanol $96 \%$ dan disari dengan menggunakan $25 \mathrm{ml}$ petroleum eter. Larutan ini dipanaskan dengan hati-hati, kemudian ditambahkan dengan $10 \mathrm{ml}$ eter dan dilihat dibawah UV $366 \mathrm{~nm}$ dimana Hasil positif menunjukkan terbentuk warna kuning intensif.

Pada uji saponin diketahui sebanyak $10 \mathrm{ml}$ larutan uji dalam tabung reaksi dikocok vertikal selama 10 detik kemudian dibiarkan selama 10 menit. 
Pembentukan busa setinggi $1-10 \mathrm{~cm}$ yang stabil selama tidak kurang dari 10 menit menunjukkan adanya saponin. Pada penambahan 1 tetes $\mathrm{HCl} 2 \mathrm{~N}$, busa tidak hilang.

Pemeriksaan steroid dan triterpenoid dilakukan dengan reaksi Liebermann-Burchard. Sebanyak $2 \mathrm{ml}$ larutan uji diuapkan dalam cawan penguap. Selanjutnya ditambahkan $2 \mathrm{ml}$ asam sulfat pekat melalui dinding tabung. Terbentuknya cincin coklat atau violet pada perbatasan larutan menunjukkan adanya triterpenoid, sedangkan bila muncul warna biru kehijauan menunjukkan adanya steroid.

Pada pemeriksaan uji alkaloid sebanyak $2 \mathrm{ml}$ larutan ekstrak uji diuapkan di atas cawan porselin hingga didapat residu. Residu kemudian dilarutkan dengan $5 \mathrm{ml}$ asam klorida $2 \mathrm{~N}$. Larutan yang didapat kemudian dibagi kedalam 5 tabung reaksi dimana dilihat perubahan warna endapan yang terbentuk (endapan putih, coklat kehitaman, coklat, dan jingga)

Untuk uji fenol, sebanyak $2 \mathrm{ml}$ larutan ekstrak uji ditambahkan pereaksi $\mathrm{FeCl} 310 \%$. Terbentuknya larutan berwarna biru kehitaman menunjukkan adanya fenol. Sedangkan untuk uji glikosida dilakukan dengan reaksi Liebermann-Burchard. Terbentuknya cincin berwarna hijau kebiruan menunjukkan adanya glikosida.

Pemeriksaan tannin dilakukan dengan menggunakan sebanyak $2 \mathrm{ml}$ larutan ekstrak uji ditambahkan pereaksi $\mathrm{Pb}$ asetat $10 \%$. Terbentuknya endapan putih pada dasar tabung menunjukkan adanya tanin. Sedangkan untuk uji minyak atsiri diketahui sebanyak 5 gram ekstrak kunyit dilarutkan dengan $10 \mathrm{ml}$ diklorometan disonikasi selama 15 menit, suspensi yang terbentuk kemudian disaring. Filtrat yang diperoleh selanjutnya diuapkan hingga kering, kemudian dilarutkan dengan $1 \mathrm{ml}$ toluena. Hasil positif ditunjukkan dengan hasil pemeriksaan berwarna biru, hijau, merah dan kuning kecoklatan

\section{Uji daya hambat ekstrak kunyit terhadap pertumbuhan bakteri Streptococcus mutans}

Konsentrasi ekstrak yang akan dibuat, yaitu konsentrasi 5\%, 10\%, 20\%, dan 40\%. Masingmasing konsentrasi ekstrak dibuat dengan cara mengencerkan ekstrak kental kunyit ke dalam etanol 96\% hingga mencapai volume total $1 \mathrm{ml}$.

Setelah itu dilakukan penjenuhan masing-masing konsentrasi ekstrak kunyit serta kontrol negatif pada blank disk. Blank disk dimasukkan ke dalam cawan petri kosong dan ditetesi ekstrak kunyit masing-masing konsentrasi serta etanol 96\% sebagai kontrol negatif dengan menggunakan mikropipet. Kontrol positif menggunakan disk antibiotik Vancomycin. Disk untuk masing-masing perlakuan disiapkan sebanyak 4 buah.
Untuk pembuatan suspensi bakteri Streptococcus mutans, isolat murni Streptococcus mutans diambil dengan ose steril dan dioleskan pada permukaan media agar MHB dalam cawan petri secara merata. Cawan petri yang berisi media agar MHB yang sudah diolesi bakteri Streptococcus mutans disiapkan sebanyak 4 buah. Masing-masing cawan petri ditempelkan 6 disk yang berisi ekstrak kunyit konsentrasi 5\%, 10\%, $20 \%$ dan $40 \%$, kontrol negatif, dan kontrol positif. Disk tersebut ditempelkan dengan menggunakan pinset steril pada permukaan media agar MHB. Seluruh cawan petri kemudian diinkubasi dalam inkubator dengan suhu $37^{\circ} \mathrm{C}$ selama 24 jam. Setelah 24 jam, zona bening yang terbentuk di sekitar disk dilihat dan diukur dengan jangka sorong lalu dicatat.

\section{Analisis Data}

Jenis data yang didapat dari penelitian ini adalah data numerik $(\mathrm{mm})$. Data didapat dari pencatatan hasil pengamatan diameter zona hambat yang terbentuk dari ekstrak kunyit pada konsentrasi 5\%, $10 \%$, 20\%, dan $40 \%$. Data yang didapat kemudian diolah menggunakan program SPSS 20 Windows. Uji analisis yang digunakan, yaitu uji KruskalWallis untuk uji komparatif dikarenakan data tidak berdistribusi normal.

\section{HASIL}

\section{Hasil Uji Fitokimia Ekstrak Kunyit}

Berdasarkan tabel di bawah dapat diketahui bahwa ekstrak kunyit positif mengandung fenol dan minyak atsiri dari hasil uji fitokimia (Tabel 1). Hasil uji fitokimia juga menunjukkan bahwa ekstrak kunyit mengandung saponin, tanin, dan flavonoid (Tabel 1)

\section{Hasil Uji Daya Hambat Ekstrak Kunyit terhadap Pertumbuhan Bakteri Streptococcus mutans}

Hasil uji daya hambat ekstrak kunyit terhadap pertumbuhan bakteri Streptococcus mutans diperoleh dari hasil pengukuran diameter zona hambat yang terbentuk pada masing-masing disk perlakuan setelah diinkubasi selama 24 jam (Gambar 3). Pengukuran dilakukan dari tepi ke tepi diameter zona hambat dengan menggunakan jangka sorong dalam satuan milimeter ( $\mathrm{mm}$ ).

Adapun hasil pengukuran diameter zona hambat ditampilkan dalam bentuk tabel yang tertera di bawah sebagai berikut (Tabel 3).

Berdasarkan data pada tabel di atas, dapat dilihat bahwa dari keenam kelompok perlakuan hanya kontrol positif menggunakan disk antibiotik 
Tabel 1 Hasil uji fitokimia ekstrak kunyit Kandungan Senyawa

\begin{tabular}{lc}
\hline Kandungan Senyawa & Hasil \\
\hline Fenol & + \\
Minyak atsiri & + \\
Steroid & - \\
Triterpenoid & - \\
Alkaloid & - \\
Saponin & + \\
Glikosida & - \\
Tanin & + \\
Flavonoid & + \\
\hline
\end{tabular}

Tabel 3 Hasil pengukuran diameter zona hambat

\begin{tabular}{|c|c|c|c|c|c|c|c|}
\hline \multirow{2}{*}{$\begin{array}{l}\text { Kelompok } \\
\text { Perlakuan }\end{array}$} & \multicolumn{5}{|c|}{ Diameter Zona Hambat (mm) } & \multirow[b]{2}{*}{ Rata-rata } & \multirow[b]{2}{*}{ Nilai $\mathbf{P}$} \\
\hline & I & II & III & IV & $\mathbf{V}$ & & \\
\hline Konsentrasi 5 \% & 0 & 0 & 0 & 0 & 0 & 0 & 0,001 \\
\hline Konsentrasi $10 \%$ & 0 & 0 & 0 & 0 & 0 & 0 & \\
\hline Konsentrasi $20 \%$ & 0 & 0 & 0 & 0 & 0 & 0 & \\
\hline Konsentrasi $40 \%$ & 0 & 0 & 0 & 0 & 0 & 0 & \\
\hline Kontrol Negatif & 0 & 0 & 0 & 0 & 0 & 0 & \\
\hline Kontrol Positif & 23 & 25 & 24 & 24 & 23 & 23,8 & \\
\hline
\end{tabular}

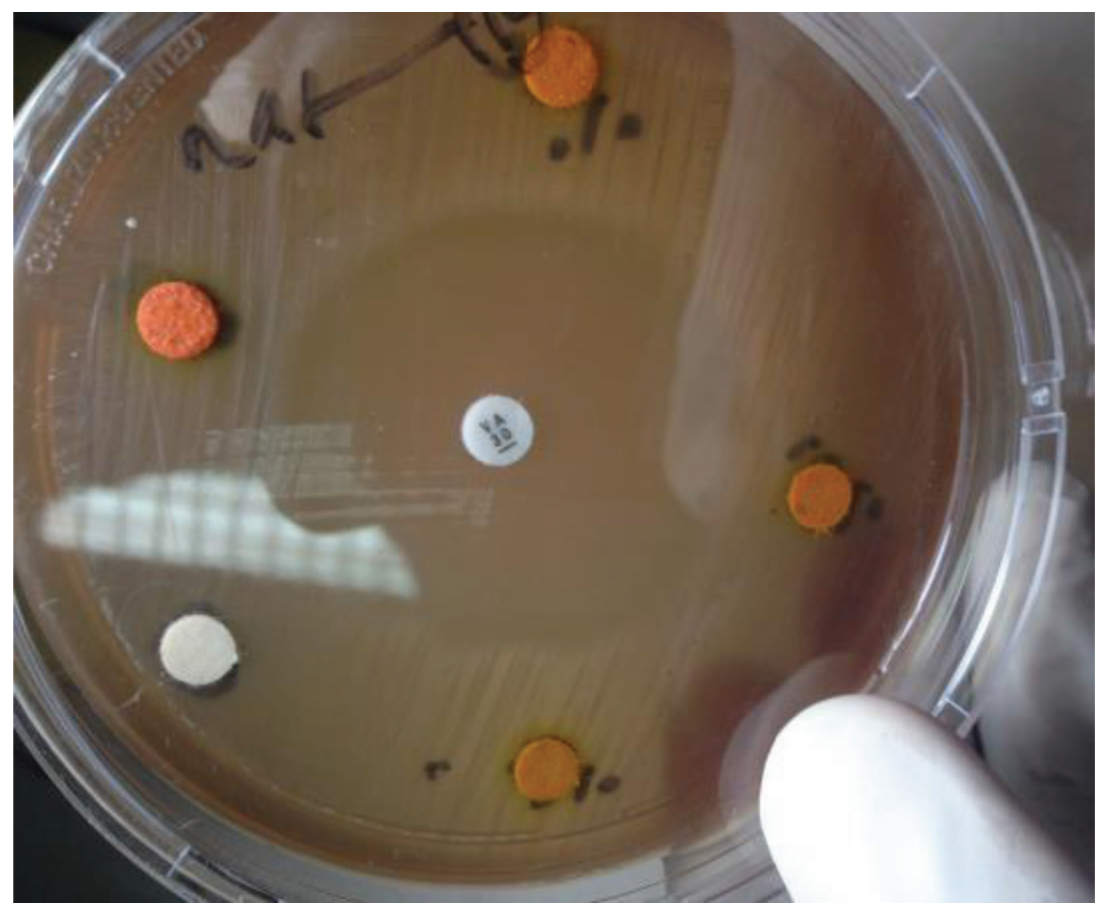

Gambar 3 Zona Hambat yang terbentuk pada diskus

vancomycin yang terdapat zona hambat dengan rata-rata diameter zona hambat sebesar 23,8 $\mathrm{mm}$. Pada ekstrak konsentrasi 5\%, 10\%, 20\%, dan 40\% serta kontrol negatif menggunakan etanol $96 \%$ tidak terdapat zona hambat yang terbentuk.
Hasil uji Kruskal-Wallis didapatkan nilai $\mathrm{p}<0,05$ yang berarti terdapat perbedaan diameter zona hambat pada keenam kelompok perlakuan secara signifikan dibandingkan dengan kontrol positif. Uji post-hoc tidak dilakukan pada penelitian ini karena dari hasil pengamatan didapatkan diameter zona hambat pada kelompok ekstrak kunyit konsentrasi 5\%, 10\%, 20\%, dan 40\% serta kontrol negatif adalah sama, yaitu $0 \mathrm{~mm}$ sehingga dapat disimpulkan bahwa ekstrak kunyit konsentrasi 5\%, 10\%, 20\%, dan 40\% tidak dapat menghambat pertumbuhan bakteri Streptococcus mutans.

\section{PEMBAHASAN}

Hasil dari uji fitokimia didapatkan bahwa ekstrak kunyit positif mengandung minyak atsiri, fenol, flavonoid, tanin, dan saponin. Kelima senyawa tersebut merupakan senyawa yang bersifat antibakteri. Fenol dapat mendenaturasi protein pada bakteri sehingga sel bakteri akan mengalami kerusakan. Kerusakan sel bakteri ini terjadi akibat penurunan permeabilitas dinding sel bakteri yang menyebabkan pertumbuhan sel terhambat dan akhirnya akan menyebabkan sel mati. ${ }^{13}$

Minyak atsiri memiliki kemampuan untuk mendenaturasi dan menghancurkan membran sitoplasma sel. Dinding sel dan membran sitoplasma bakteri yang tidak stabil akan mengganggu permeabilitas, fungsi transport aktif, dan kontrol protein sel bakteri. Integritas sitoplasma yang terganggu tersebut akan menyebabkan sel bakteri mengalami lisis. ${ }^{14}$ Flavonoid dapat menyebabkan kerusakan pada dinding sel bakteri. Dinding sel bakteri yang rusak akan menyebabkan naiknya permeabilitas sel membran sehingga cairan dari luar sel masuk ke dalam sel dan mengakibatkan pecahnya sel bakteri. ${ }^{9,15}$

Tanin dapat membentuk ikatan hidrogen dengan protein sel bakteri. Jika tanin berhasil membentuk ikatan hidrogen dengan protein sel bakteri, maka akan menyebabkan perubahan molekul protein sel bakteri. Perubahan molekul protein ini dapat menyebabkan terganggunya metabolisme sel bakteri. ${ }^{16}$ Saponin memiliki kemampuan untuk meningkatkan permeabilitas sel membran sehingga menjadi tidak stabil dan terjadi hemolisis sel. ${ }^{5}$ Saponin juga memiliki kemampuan untuk mengganggu tegangan permukaan dinding sel bakteri. Saat tegangan permukaan dinding sel bakteri terganggu, maka senyawa antibakteri yang lain dapat dengan mudah masuk ke dalam sel bakteri dan mengganggu metabolisme sel sehingga terjadi kematian bakteri. ${ }^{17}$

Berdasarkan hasil uji fitokimia dapat diketahui bahwa ekstrak kunyit memiliki senyawa-senyawa 
yang bersifat antibakteri. Hal ini juga didukung dengan penelitian yang dilakukan oleh Pangemanan dkk. pada tahun 2016. Pangemanan dkk. meneliti daya hambat ekstrak kunyit konsentrasi 5\%, 10\%, $20 \%$, dan $40 \%$ terhadap pertumbuhan bakteri Staphylococcus aureus dan Pseudomonas sp. Hasil dari penelitian tersebut menunjukkan bahwa ekstrak kunyit konsentrasi 5\%, 10\%, 20\%, dan $40 \%$ dapat menghambat pertumbuhan bakteri Staphylococcus aureus dan Pseudomonas sp. ${ }^{11}$

Ketiadaan zona hambat pada ekstrak kunyit dapat disebabkan oleh beberapa faktor, yaitu faktor perbedaan metode uji daya hambat, metode pengeringan ekstrak yang digunakan, konsentrasi ekstrak, dan perbedaan kandungan kunyit. Metode uji daya hambat yang digunakan pada penelitian sebelumnya adalah metode well-diffusion, sedangkan pada penelitian ini menggunakan metode disk-diffusion. Metode well-diffusion merupakan metode uji daya hambat dengan membuat suatu lubang sumuran pada media pembiakan bakteri. Lubang berdiameter 6-8 $\mathrm{mm}$ tersebut diisi dengan zat antibakteri yang ingin diuji dan kemudian diinkubasi dengan kondisi yang sesuai tergantung bakteri yang diuji. ${ }^{18}$

Prayoga pada tahun 2013 meneliti perbandingan efek ekstrak daun sirih dengan metode disk-diffusion dan well-diffusion terhadap pertumbuhan bakteri Staphylococcus aureus. Hasil dari penelitian tersebut menunjukkan bahwa terdapat perbedaan efek ekstrak daun sirih terhadap pertumbuhan bakteri Staphylococcus aureus pada metode disk-diffusion dan well-diffusion. Perbedaan tersebut tampak dari rata-rata diameter zona hambat yang terbentuk, di mana pada metode well-diffusion memiliki rata-rata diameter zona hambat yang lebih besar dibandingkan metode disk-diffusion dengan konsentrasi ekstrak yang sama. ${ }^{19}$

Perbedaan diameter zona hambat pada metode disk-diffusion dan well- diffusion terjadi karena perbedaan osmolaritas yang dimiliki oleh kedua metode. Metode well-diffusion perlu membuat lubang yang kemudian diisi dengan zat yang ingin diuji. Zat uji yang diisi pada lubang tersebut memiliki osmolaritas yang lebih menyeluruh dan homogen sehingga dapat menghambat pertumbuhan bakteri lebih baik. ${ }^{19}$ Penggunaan metode disk-diffusion pada penelitian ini karena metode disk-diffusion merupakan metode uji daya hambat bakteri yang sudah distandardisasi untuk beberapa bakteri, salah satunya adalah bakteri Streptococcus. ${ }^{18}$

Metode pengeringan yang dipakai pada penelitian ini adalah pengeringan dengan sinar matahari langsung. Pengeringan dengan sinar matahari langsung menyebabkan berkurangnya kandungan senyawa aktif yang terkandung pada ekstrak. Penelitian yang dilakukan oleh Utomo dkk. pada tahun 2009 mengenai pengaruh metode pengeringan terhadap kandungan flavonoid pada ekstrak sambiloto (Andrographis paniculata) menunjukkan bahwa pengeringan dengan sinar matahari langsung memiliki kandungan flavonoid yang lebih rendah dibandingkan pengeringan dengan oven dan pengeringan dengan sinar matahari tidak langsung. Perolehan kandungan flavonoid dari yang terendah hingga tertinggi, yaitu pengeringan dengan sinar matahari langsung, pengeringan dengan oven, dan pengeringan dengan sinar matahari tidak langsung. ${ }^{20}$

Penelitian yang dilakukan oleh Oktaviana pada tahun 2010 juga menunjukkan hal yang serupa. Penelitian oleh Oktaviana mengenai pengaruh metode pengeringan terhadap kandungan kurkuminoid pada ekstrak temulawak (Curcuma xanthorrhiza) menunjukkan bahwa pengeringan dengan sinar matahari langsung memiliki kandungan kurkuminoid yang paling rendah. ${ }^{21}$ Ekstrak kunyit mengandung flavonoid dan kurkuminoid, sehingga pengeringan dengan sinar matahari langsung menyebabkan berkurangnya kandungan flavonoid dan kurkuminoid pada kunyit. Berkurangnya kandungan flavonoid dan kurkuminoid ini menyebabkan menurunnya efektivitas ekstrak kunyit dalam menghambat pertumbuhan bakteri Streptococcus mutans.

Konsentrasi ekstrak kunyit yang digunakan pada penelitian ini adalah konsentrasi 5\%, 10\%, $20 \%$, dan $40 \%$. Pemilihan konsentrasi tersebut didasarkan pada hasil penelitian sebelumnya yang dilakukan oleh Pangemanan dkk., di mana ekstrak kunyit konsentrasi 5\%, 10\%, 20\%, dan 40\% dapat menghambat pertumbuhan bakteri Staphylococcus aureus dan Pseudomonas sp..$^{11}$ Konsentrasi yang digunakan pada penelitian ini masih rendah dan dapat ditingkatkan. Konsentrasi ekstrak berpengaruh terhadap kemampuan ekstrak dalam menghambat pertumbuhan bakteri. Peningkatan konsentrasi ekstrak akan meningkatkan kandungan senyawa antibakteri yang terdapat pada ekstrak sehingga daya hambat ekstrak semakin kuat. ${ }^{15,17}$

Faktor yang terakhir adalah faktor perbedaan kandungan kunyit. Kandungan kunyit dipengaruhi oleh sumber tanaman, iklim, kondisi tanah, dan faktor demografi lainnya. Kualitas dan kuantitas kandungan kunyit juga dipengaruhi oleh waktu pemanenan tanaman. ${ }^{22}$ Penelitian ini menggunakan tanaman kunyit yang berbeda dengan penelitian sebelumnya. Perbedaan ini menyebabkan kandungan kunyit pada penelitian ini berbeda dibandingkan dengan kandungan kunyit pada penelitian sebelumnya baik secara kualitas maupun kuantitas. Kandungan kunyit mempengaruhi jumlah senyawa antibakteri yang dikandung sehingga mempengaruhi efektivitas daya hambat ekstrak kunyit terhadap pertumbuhan bakteri Streptococcus mutans. 


\section{SIMPULAN}

Ekstrak kunyit konsentrasi 5\%, 10\%, 20\%, dan 40\% tidak dapat menghambat pertumbuhan bakteri Streptococcus mutans. Ketiadaan zona hambat pada ekstrak kunyit disebabkan oleh faktor perbedaan metode uji daya hambat, metode pengeringan ekstrak yang digunakan, konsentrasi ekstrak, dan perbedaan kandungan kunyit. Oleh karena itu, perlu dilakukan penelitian lebih lanjut mengenai daya hambat ekstrak kunyit terhadap pertumbuhan bakteri Streptococcus mutans dengan metode pengeringan ekstrak yang lebih baik.

\section{KONFLIK KEPENTINGAN}

Tidak terdapat konflik kepentingan dalam pembuatan laporan hasil penelitian.

\section{PERSETUJUAN ETIK}

Penelitian ini telah memperoleh persetujuan dari komisi etik sebelum dijalankan.

\section{PENDANAAN}

Penulis bertanggung jawab terhadap pendanaan penelitian ini tanpa melibatkan pihak sponsor.

\section{KONTRIBUSI PENULIS}

Para penulis berkontribusi secara sama dalam pembuatan laporan hasil penelitian baik dari perancangan tulisan, pengambilan sampel, analisis data, hingga laporan penelitian.

\section{DAFTAR PUSTAKA}

1. Karpinski TM, Szkaradkiewicz AK. Microbiology of Dental Caries, J Biol Earth Sci, 2013; 3(1):21-24.

2. Badan Penelitian dan Pengembangan Kesehatan. Riset Kesehatan Dasar (Riskesdas) 2007. Jakarta. 2008: 142.

3. Badan Penelitian dan Pengembangan Kesehatan. Riskesdas 2013 dalam Angka, Jakarta. 2013: 189.

4. Indah IZ, Intan SA. Penyakit Gigi, Mulut, dan THT. Nuha Medika.Yogyakarta. 2013: 18.

5. Dewi ZY, Nur A, Hertriani T. Efek Antibakteri dan Penghambatan Biofilm Ekstrak Sereh (Cymbopogon nardus L.) terhadap Bakteri Streptococcus mutans. Maj Ked Gi Ind. $2015 ; 1(2)$ : 136-141

6. Salman HA, Senthikumar R. Identification and Antibiogram Profile of Streptococcus mutans and Streptococcus sobrinus from Dental Caries Subjects. J App Pharm Sci. 2015; 5(6): 54-57.

7. Metwalli KH, Khan SA, Krom BP, Jabra-Rizk MA. Streptococcus mutans, Candida albicans, and The Human Mouth: A Sticky Situation. PLoS Pathog. 2013; 9(10):1-5.
8. Kuswiyanto. Bakteriologi 2: Buku Ajar Analis Kesehatan. EGC. Jakarta. 2014: 19.

9. Rieuwpassa IE, Hamrun N, Lukman SR, Reski YS, Ramadhani S. Ekstrak Buah Kaktus Pir Berduri Menghambat Pertumbuhan Staphylococcus aureus, Streptococcus mutans, dan Candida albicans. Dentofasial. 2013; 12(3): 139-143.

10. Ahmad T, Singh SB, Pandey S. Phytochemical Screening and Physicochemical Parameters of Crude Drugs: A Brief Review. International Journal of Pharma Research \& Review. 2013; 2(12):53-60

11. Pangemanan A, Fatimawali, Budiarso F. Uji Daya Hambat Ekstrak Rimpang Kunyit (Curcuma longa) terhadap Pertumbuhan Bakteri Staphylococcus aureus dan Pseudomonas sp. Jurnal e-Biomedik. 2016; 4(1):81- 85.

12. Saridewi MN, Bahar M, Anisah. Uji Efektivitas Antibakteri Perasan Jus Buah Nanas (Ananas comosus) terhadap Pertumbuhan Isolat Bakteri Plak Gigi di Puskesmas Kecamatan Tanah Abang Periode April 2017. Biogenesis. 2017; 5(2):104-110.

13. Alibasyah ZM, Andayani R, Farhana A. Potensi Antibakteri Ekstrak Jahe (Zingiber officinale Roscoe) Terhadap Poryphyromonas gingivalis secara In Vitro, J Syiah Kuala Dent Soc. 2016; 1(2):147-152.

14. Fajriani, Mahrum. Effectiveness of lime (Citrus aurantifolia) extract solution in inhibiting bacteria Streptococcus mutans case of early childhood caries. Donn J Dent Oral Hyg. 2015; 1(4):16-20.

15. Adila R, Nurmiati, Agustien A. Uji Antimikroba Curcuma spp terhadap Pertumbuhan Candida albicans, Staphylococcus aureus, dan Escherichia coli. J. Bio. UA. 2013; 2(1):1-7.

16. Mailoa $\mathrm{MN}$, Mahendradatta $\mathrm{M}$, Laga A, Djide $\mathrm{N}$. Antimicrobial Activities of Tannins Extract from Guava Leaves (Psidium Guajava L.) on Pathogens Microbial. International Journal of Scientific \& Technology Research. 2014; 3(1):236-241.

17. Karlina CY, Ibrahim M, Trimulyono G. Aktivitas Antibakteri Ekstrak Herba Krokot (Portulaca oleracea L.) terhadap Staphylococcus aureus dan Escherichia coli. LenteraBio. 2013; 2(1):87-93.

18. Balouiri M, Sadiki M, Ibnsouda SK. Methods for In Vitro Evaluating Antimicrobial Activity: A Review. Journal of Pharmaceutical Analysis. 2016; 6:71-79.

19. Prayoga E. Perbandingan Efek Ekstrak Daun Sirih Hijau (Piper betle L.) dengan Metode Difusi Disk dan Sumuran terhadap Pertumbuhan Bakteri Staphylococcus aureus. Fakultas Kedokteran dan Ilmu Kesehatan Universitas Islam Negeri Syarif Hidayatullah. Jakarta. 2013: 18-22.

20. Utomo AD, Rahayu WS, Dhiani BA. Pengaruh Beberapa Metode Pengeringan terhadap Kadar Flavonoid Total Herba Sambiloto (Andrographis paniculata). PHARMACY. 2009; 6(1):58-68

21. Oktaviana PR. Kajian Kadar Kurkuminoid, Total Fenol, dan Aktivitas Antioksidan Ekstrak Temulawak (Curcuma Xanthorriza Roxb.) pada Berbagai Teknik Pengeringan dan Proporsi Pelarutan. Fakultas Pertanian Universitas Sebelas Maret. Surakarta. 2010; 28-30.

22. Prengki OF. Husin UA, Widayanti, Yuniarti L. Resistensi Streptococcus mutans ATCC 35668 terhadap Fraksi Etil Asetat Daun Sirsak (Annona muricata Linn). Prosiding Pendidikan Dokter. 2016; 2(2):371- 375.

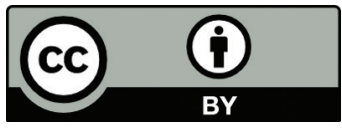

This work is licensed under a Creative Commons Attribution 